\title{
THE PREVALENCE OF LICE AND FLEAS OF CHICKENS IN BOKKOS LOCAL GOVERNMENT AREA OF PLATEAU STATE, NIGERIA
}

MATUR BERNARD MALAU and NOAMI JAMES RUGU

(Received 27 October 1999; Revision accepted 15 December 2000)

\begin{abstract}
The study of ectoparasitic fauna of poultry in Bokkos Local Government Area of Plateau State, was conducted from September 1991 to May 1992. Two (2) species or ectoparasitic lice; Menacanthus coruntors and Amyrsidea Powelli and one (1) specie of flea; Echidnophaga gallinacea were identified to have slightly high percentage prevalence of $48.14 \%$ and $51.76 \%$ respectively. Adult birds ( 6 weeks and above) recorded the highest infestation rate $(100 \%)$ than younger birds, $1-2$ weeks (12\%) and 3-5 weeks (86\%). It was also observed that adult female birds had the highest rate of infestation (61.18\%) than males $(38.32 \%)$. A statistical test carried out using the studentized t-test revealed that female birds were more susceptible to infestation than male $(\mathrm{P}<0.05)$.
\end{abstract}

KEY WORDS: Ectoparasites, Lice, Flea, Infestation.

\section{INTRODUCTION}

Poultry means domesticating tame birds for the purpose of obtaining meat, eggs and for other uses in research institutions and certain religious practices. Poultry consist of various species of birds, amongst which include the species of chickens (Gallus gallus domestica), turkeys (Meleagridis galloparo) and ducks (Ansa sparsa). They are found throughout the world (McC'raw-hill, 1974; Hickman, 1979 and Okpala, 1982).

Birds like other warm blooded animals harbaur different species of ectoparasites. The presence of feathers covering almost two-third of the entire body surface creates a favourable environment for the ectoparasites to live on (Fabiyi, 1980). Jatau (1990), reported that the feathers on the head, neck, ventral and dorsal surface together with some parts of the legs are the major predilection sites of the ectoparasites Ectoparasites that are most commonly found on domestic birds (Gallus gallus domestica) are several species of lice (Menacanthus coruntors, Amyrsidea powelli, Numiditiperirus tropicalis, Gonicotes gallinea, Lipericus corporis and Goniodes gigas), fleas (Echidnophage gallinacea), ticks, mites and dipterous flies (Fabiyi, 1972).

Apart from causing restlessness and discomfort, they act as yectors of diseases ranging from bacteria, fungi, virus and protozoans (Adene and Dipealu, 1975).
They also cause damage/ to the skin of the animal thereby creating room for secondary infection most especially dipterous larvae (Soulsby, 1975). According to Loomis (1984) and Wallace, Shawn and Harbour (1990), the activities of ectoparasites could lead to low level of meat and egg production and thus finally reduce the nutritional value of the birds. This study is aimed at determining the ectoparasites that infest chickens (Galus' gallus domestica) in the study area and to adopt ways of improving poultry management and production and control of ectoparasitic infestation in order to improve healthy growth of the animai and increase egg and meat production for the community .

\section{MATERIALS AND METHOD Sample Collection}

The study of ectoparasites was carried out in seven villages (Butura, Kunet, Mbar, Mushere. Maikatako, Kwatas and Bot) within Bokkos Local Government Area. The free range birds were grouped into three categories (1-2 weeks old, 3-5 weeks old and 6 weeks and above) and examined. The adult age group ( 6 weeks and above) were further separated into males and females for effective comparison of the infestation rates. The ectoparasites were collected by using a pair of furcep, and direct hand-picking at certain instances where many 
ectoparasites were found at the same site. The specimens were then preserved inside bijou bottles containing $5-10 \mathrm{~m} /$ of $70 \%$ alcoliol, before identification was carried in the laboratory, according to the method of Fabiyi (1972 and 1980) and modified by Tanwia (1990).

\section{RESULTS}

Of the three hundred (300) birds exarrined for ectoparasites, $198(66.99 \%)$ were infested with lice (Menacanthus coruntors and dmyrsidea powelli) and flea (Echidnophaga gallinacea), Table 1.

The three different age groups had ectoparasitic infestation of lice (Menacanthus coruritors and Amyrsidea powelli) and flea (Echionophaga gallinacea). The two species of lice identified were recovered from all the age groups with a very high rate occuring in the adults $(100 \%)$ and the middle age $(86 \%)$ than the young age group (1-2weeks) which recorded only $12 \%$ (Table 1$)$. But the species of flea (Echidnophage gallinacea) recovered was only found on the adult birds. Results from table 2 revealed that, fernale birds has high rate of susceptibility $(61.18 \%)$ to parasitic infestation than the males $(38.82 \%)$.

The intensity of infection by the ectoparasite shows that an average number of 30 lice and 12 flea were recovered from each adult male chicken and 43 lice and 20 flea from each fenale respectively (Table 2 ).

The percentage prevalence rate of the three species of ectoparasites on the domestic birds revealed that Menacanthus coruntors and Amyrsidea powelli recorded $48.14 \%$ infestation rate while Echidnophage gallinacea recorded $51.76 \%$, Also the distribution of the parasites was relatively high during the months of September and November (Table 3).

\section{DISCUSSION}

The comparative study on the rates of infestation of ectoparasites on various age groups of chickens (Gallus domesica) shows that domestic birds within the age of $1-2$ weeks had little infestation (12\%), this value is relatively low as compared to $86 \%$ and $100 \%$ of the middle and adult-age groups respectively. It

TABI.E 1:

INFESTATION RATE OF ECTOPARASITES ON VADOUS AGE GROUPS OF CHICKEN

\begin{tabular}{|l|l|l|l|}
\hline Chiken (age) & No. Observed & No. Infested & $\%$ Infested \\
\hline $1-2$ Wecks & 100 & 12 & 12 \\
\hline $3-5$ Weeks & 100 & 86 & 86 \\
\hline 6 Weeks and Above & 100 & 100 & 100 \\
\hline Tolal & 300 & 198 & 66.0 \\
\hline
\end{tabular}

TABLE 2:

INFESTATION RATE OF ECTOPARASITE ON ADULT MALE FEMALE BIRDS

\begin{tabular}{|l|l|l|l|l|l|l|}
\hline Sex & No. Observed & No. of Lice & No. of Flea & No. of Lice \& Flea & Total No. of Parasite & \% Prevalcne \\
\hline Male & 50 & 30 & 12 & 17 & 59 & 38.82 \\
\hline Female & 50 & 43 & 20 & 30 & 93 & 61.18 \\
\hline Total & 100 & 73 & 32 & 47 & 152 & \\
\hline
\end{tabular}

TABLE 3:

THE RELATIVE ABUNDANCE OFTHE. SPECIE OF ECTORPARASITES RECOVERED DURING THE STUDY PERIOU

\begin{tabular}{|c|c|c|c|c|c|c|c|c|c|c|}
\hline Specie & Sept'91 & Oet'91 & Nov'91 & Dec'91 & Jan'92 & Feb'92 & Mar'92 & Apr'92 & $\begin{array}{l}\text { Total } \\
\text { Prevalence }\end{array}$ & \%Prevalence \\
\hline $\begin{array}{l}\text { Menicanthus } \\
\text { Coruntors }\end{array}$ & 136 & 122 & 137 & 113 & $110^{\circ}$ & 16 & 113 & 114 & 861 & 43.31 \\
\hline $\begin{array}{l}\text { Amyrsidea } \\
\text { Powelli }\end{array}$ & 12 & 11 & 17 & 11 & 11 & 12 & 12 & 12 & 96 & 4.83 \\
\hline Total for Lice & & & & & & & & & 957 & 48.14 \\
\hline $\begin{array}{l}\text { Echidnophaga } \\
\text { gallinureed, }\end{array}$ & 148 & 131 & 154 & 123 & 116 & 115 & 122 & 12 & 1029 & 51.76 \\
\hline Total & 296 & 264 & 308 & 247 & 237 & 143 & 247 & 246 & 1988 & \\
\hline
\end{tabular}


was observed that the high rate of infestation by these species of ectoparasites on the adult birds made them to appear restless, have ruffled feathers they also appear generally weaker than less infested bird due to low level of nutrition. The other investigation on the sex of the birds (table 2) revealed that, of the 100 adult birds sampled, all had ectoparasites (100\% infestation) and the highest rate of distribution of these parasites was recorded in female birds $(61.10 \%)$ than males $(38.82 \%),(p<0.05)$. From the analysis on the relative distribution of the parasite (table 3 ), fleas were observed to have the highest percentage prevalence $(51.76)$ than the two species of lice $(48.9 \%)$. The trend of infestation was observed to increase as the birds increased in age. This might be as a result of the increase in surface area, which ultimately leads to increase in the development of adequate microhabitat for the ectoparasites, and to a lesser extent decrease in immunity as the bids grow older. Female bird which had a high percentage prevalence rate than male spend most of their time inside the nest during egg laying and brooding, and ectoparasites remain hidden inside the nest of the birds at day time with only a few of them clinging to the host body. Also, older birds have large surface area which creates more favorable microhabitat than the younger ones (Soulsby, 1975).

The increase in the distribution of these parasites around September and November (table 3) indicates that, certain climatic factors: (e.g temperature and moisture) contributed to their high development. For instance, these months (September and October) that had high relative humidity and temperature readings could provide optimum conditions that favours the increase in development and distribution of the parasites. Adequate knowledge of these factors and the nature and behaviour of the parasites would increase poultry production if more efforts are made to improve the sanitary conditions for their environments of waste products and also disinfect the birds and poultry houses of parasites using insecticides during these months.

\section{REFERENCES}

Adene, D. F. and Dipeolu, O. O., 1975. Survey of blood and ectoparasites of domesic fowls in Ibadan, Western Nigeria, Anim. Hilth production Aprl. 223:333338

Fabiyi, J. P., 1972. The Occurrence of
Cuclotogaster oceidentalis and Amyrisea SP. powelli group (Mallophaga: Insecta) on the domestic fowl in the Vom Area of Nebue-Plateau State, Nigeria. Vec. Dec. 91: 199.

Fabiyi, J. P., 1980. Survey of lice infesting domestic fowl in the Jos plateau, Northern Nieria. Bull, Anim. Hilth. Prod. Afri. 28:215-219.

Hickman, C. P., 1979. Integrated principle of Zoology, $6^{\text {th }}$ edition. The C. V. Mosby Company St. Louis Toronto, London, $410 \mathrm{pp}$.

Jatau Emegha E. J., 1990. Ectoparasitic fauna of poultry birds in Minna and Environs. B.Sc Thesis, Department of Zoology, Uni. Jos. 65pp.

Loomis, E. C. 1984. External Parasites and Disease of Poultry E. D. Hofsaid; M. S. $8^{\text {th }}$ edition. IOWA State University Press, USA .

McGraw-Hill, 1974. Distionary of Biological terms, British Publishing Company $1785 \mathrm{pp}$.

Okpala, C. U., 1982. Incidence of Parasites on Domestic Birds in Nsukka Zope of Anambra State. B.Sc.Thesis, department of Zoology, University of Jos, 84pp.

Soulsby, E. I. J., 1975: Helmniths, Arthropods and Protozoans of Domestic Animals. 7th Edition, Bailliere and Yiridau, Lendon.

Tanwia, N. N., 1990: A Study of the Incidence and Distribution of fleas of Livestock in some Local Government of Platcau State. Ph.D Thesis, Zoology Department, Univ. of Jos.

Wallace, A. G. Shawn, R.D. and Harbour, H. E., 1990: Cattle Tick Control, A Well reseaıch Organization, Wellcome Foundation (LED), London. 